\title{
Analysis Work Accident of Work Accident of Employee Accident in CV. Pasific Harvest Muncar Banyuwangi District
}

\section{Hadi Nur Efendi}

Magister of Public Health Program of Stikes Surya Mitra Husada Kediri

Email:

hadinur46efendi@gmail.com
Received: March 12, 2019

Accepted : April 13, 2019

Published : May 10, 2019

\begin{abstract}
Occupational accident is one of the most frequent problems with workers in the company. This work accident usually occurs because of the factor of the worker himself and the working environment which in this case is from the employer. The purpose of this study is to analyze the most dominant factors that affect the workplace accident prevention efforts on the occurrence of work accidents in CV. Pacific Harvest Muncar Banyuwangi. The research design used was cross sectional. The research population is All employees in the production department CV. Pacific Harvest of 273 people and a large sample of 162 people. The sampling technique using Simple random sampling and data collection using questionnaire then analyzed using logistic regression. The results showed that there is influence of $\mathrm{K} 3$ assurance against work accident ( $\mathrm{p}$-value $=0,022<0,05)$; there is effect of $\mathrm{K} 3$ training to work accident ( $\mathrm{p}$-value $=0,039<0,05)$; there is influence of APD to work accident ( $\mathrm{p}$-value $=0,023<0,05$ ); no effect of workload on work accident ( $\mathrm{p}$-value $=0,938>0,05)$; and There is no effect of working hours on work accidents ( $\mathrm{p}$-value $=0.699>0.05$ ). The conclusion is expected for the respondent to pay more attention to health and safety while doing his job because of the many factors that can cause the work accident, the use of personal protective equipment according to the rules and always pay attention to the condition of the field and safe action in work will decrease the risk of accident work.
\end{abstract}

Keywords: Prevention effort, work accident

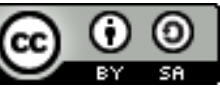

This is an open-acces article distributed under the terms of the Creative Commons Attribution-ShareAlike 4.0 International License.

\section{INTRODUCTION}

Occupational accident is one of the most frequent problems with workers in the company. This work accident usually occurs because of the factor of the worker himself and the working environment which in this case is from the employer. Occupational safety and health is one aspect of labor protection regulated in Law Number 13 Year 2003. In this labor legislation one of which contains work safety namely article 86 states that every organization is obliged to apply safety and health efforts to protect the safety labor and article 87 require every organization to implement a work safety and health management system that is integrated with the management of other organizations (Aswar, 2016).

The number of occupational accidents in Indonesia decreased in 2010 to 2011, proving that accidents can be prevented in the workplace, but the mortality rate in accidents does not go down. In 
2010, the number decreased from 98,711 to 86,368 cases in 2011. Handaya, Director General of Manpower Supervision Supervision of the Ministry of Manpower and Transmigration, said that the high number of deaths in accidents due to traffic accidents experienced by workers when leaving to return home, work accident. While the factors of workers and the environment and facilities of personal protective equipment that is not sufficient to determine the amount of the proportion of work accidents (Djumena, 2011). According to Setiajit the head of East Java's Disnakertrans said that East Java emergency work accident because in a year in 2017, there were 14,552 accidents in the company area. While accidents outside the company area reached 1,755 cases (Detiknews, 2017).

According to Government Regulation no. 50 Year 2012 definition of K3 is all activities to ensure and protect the safety and health of the workforce through prevention of occupational injuries and occupational diseases. Therefore, in the company required a management system that will regulate and run this OSH program called the Occupational Safety and Health Management System (SMK3). The objective of SMK3 is to improve the effectiveness of planned, measurable, structured and integrated occupational safety and health safeguards, prevent and reduce occupational injuries and diseases by involving management, labor / worker / union / union elements, safe, comfortable and efficient work to encourage productivity (Taufik, 2015).

There are two causes of occupational injuries: direct and basic causes. The cause of work injuries directly there are two include unsafe and unsafe acts. Unsafe actions include operating unauthorized devices / equipment, failing to alert, failing to secure, working at the wrong speed, removing safety equipment, using defective devices, using the tools in the wrong way, not wearing proper protective / safety equipment, disassemble and misplaced. Unsafe conditions (Unsafe condition) (Efendy and Makhfudli, 2010).

Based on the above description, the authors are interested to examine "Analysis of work accident prevention efforts against the occurrence of work accidents in the CV. Pacific Harvest Muncar Banyuwangi".

\section{MATERIALS AND METHODS}

The design used in this study is cross-sectional. The population is all employees in the production CV. Pacific Harvest Muncar Banyuwangi Regency as many as 273 people. The sample size is 162 respondents using simple random sampling technique. Independent research variables are K3 assurance, OHS training, use of PPE, workload, and working hours. Dependent variable is work accident. Data were collected using quesionnaire, then the data were analyzed using logistic regression test with significance level $\alpha \leq 0,05$.

\section{RESULTS}

Table 1. Frequency distribution based on K3 assurance

\begin{tabular}{ccc}
\hline K3 assurance & $\mathrm{n}$ & $\mathrm{f}(\%)$ \\
\hline No & 118 & 72,8 \\
\hline Yes & 44 & 27,2 \\
\hline Total & 162 & 100 \\
\hline
\end{tabular}

Source: Primary data of research in 2018

Based on the table 1 indicates that of 162 respondents mostly do not have K3 (BPJS) guarantee that is as much as 118 respondents $(72.8 \%)$. 
Table 2. Distribution of frequency based on K3 training

\begin{tabular}{ccc}
\hline K3 Training & $\mathrm{n}$ & $\mathrm{f}(\%)$ \\
\hline Never & 92 & 56,8 \\
\hline Ever & 70 & 43,2 \\
\hline Total & 162 & 100 \\
\hline
\end{tabular}

Source: Primary data of research in 2018

Based on table 2 shows that of 162 respondents mostly never attended the K3 training that is 92 respondents $(56,8 \%)$.

Table 3. Distribution of frequency based on the use of PPE

\begin{tabular}{ccc}
\hline Use of PPE & $\mathrm{n}$ & $\mathrm{f}(\%)$ \\
\hline Not in accordance & 5 & 3,1 \\
\hline Corresponding & 157 & 96,9 \\
\hline Total & 162 & 100 \\
\hline
\end{tabular}

Source: Primary data of research in 2018

Based on ta bell 3 shows that of 162 respondents almost entirely the use of appropriate category APD that is as many as 157 respondents (96.9\%).

Table 4. Frequency distribution based on workload

\begin{tabular}{ccc}
\hline Workload & $\mathrm{n}$ & $\mathrm{f}(\%)$ \\
\hline Light & 140 & 86,4 \\
\hline Medium & 22 & 13,6 \\
\hline Weight & - & - \\
\hline Very heavy & - & - \\
\hline Very heavy & - & - \\
\hline Total & 162 & 100 \\
\hline
\end{tabular}

Source: Primary data of research in 2018

Based on table 4 shows that of 73 respondents most light category workload that is as many as 140 respondents $(86.4 \%)$.

Table 5. Distribution of frequency based on working hours

\begin{tabular}{ccc}
\hline Jam Kerja & $\mathrm{n}$ & $\mathrm{f}(\%)$ \\
\hline Not in accordance & 14 & 8,6 \\
\hline Corresponding & 148 & 91,4 \\
\hline Total & 162 & 100 \\
\hline
\end{tabular}

Source: Primary data of research in 2018

Based on table 5 shows that of 162 respondents almost all working hours appropriate category is as many as 148 respondents $(91.4 \%)$. 
Table 6. Frequency distribution by accident

\begin{tabular}{ccc}
\hline Accident & $\mathrm{n}$ & $\mathrm{f}(\%)$ \\
\hline Never & 150 & 92,6 \\
\hline Ever & 12 & 7,4 \\
\hline Total & 162 & 100 \\
\hline
\end{tabular}

Sumber : Data primer penelitian tahun 2018

Based on Table 6 shows that from 162 respondents almost never had an accident that is as much as 150 respondents $(92.6 \%)$.

Based on the backward logistic regression table: LR shows that from the five variables after the logistic regression test there are only three variables that affect work accidents in CV. Pacific Harvest Muncar Banyuwangi, namely BPJS ( $\mathrm{p}=0.016$; $\mathrm{OR}=0.208)$, K3 Training $(\mathrm{p}=0.038$; OR = $6,268)$ and use of APD ( $=0.018$; OR = 16.160). This means that if the employee does not have K3 (BPJS) assurance, then the employee has an accident risk of 0.158 times greater than the employee who has K3 assurance. So also with employees who do not have training K3 training, then the employee has an accident risk of 6.268 times greater than employees who have K3 training. Similarly, employees who use PPE according to K3, then the employee has a risk of not having an accident 1 6,160 times greater than employees who have to use APD is not appropriate. So it can be concluded that the most dominant factor affecting $\mathrm{Y}$ (work accidents) is the K3 assurance factor with an influence of 6.268 times.

\section{DISCUSSION}

\section{A. Occupational safety factor against work accident}

Based on the results of this study showed that from 162 respondents most of them do not have $\mathrm{K} 3$ assurance and never had an accident as much as 113 respondents $(69,8 \%)$, and statistic test of logistic regression with result of $p$-value $=0,022$, which means $<0,05$, so $\mathrm{H} 1$ accepted and Ho rejected which means there is influence of $\mathrm{K} 3$ assurance against work accident in CV. Pacific Harvest Muncar Banyuwangi.

The results of this study are similar to previous research conducted by Safrianto (2017) which examines the effect of the provision of work accident insurance and mortality guarantee bpjs employment on employee productivity PT. Mitsubishi Krama Yudha Motors \& Manufacturing. This study shows that work accident insurance and job mortality guarantee have positive and significant influence either partially or simultaneously. Working death insurance is more influential when compared with work accident insurance against work productivity.

Workers' occupational safety and health assurance should be prioritized or prioritized and taken into account in order for workers to feel secure about the work they are doing, both at risk and not (Kusuma, 2010).

Social security in Indonesia has two aspects: providing basic protection to meet minimum living needs for workers and their families, and rewarding workers who have dedicated their energy and thought to the company. Such safeguards are intended to secure workers' rights and ensure equality of opportunity of treatment without being discriminated on any grounds to achieve prosperity (Trijono, 2014).

The results showed that the company has not fully granted the rights to employees by including safety and health insurance that is BPJS employment. In this study, the safety assurance of employees is BPJS health. Because hundreds of employees in the production CV. Pacific Harvest includes wholesale labor, so the company does not include employees in BPJS employment. This is consistent with Table 4.4 indicating that of 162 respondents mostly do not have K3 (BPJS) guarantee that is 118 respondents $(72,8 \%)$. The company has not provided or included employees into the BPJS employment guarantee. So far, their safety guarantee has only BPJS health. 
The existence of BPJS employment is expected by all employees, so that in carrying out the work of employees do not have a sense of doubt and worry if something happens at work, because there are guarantees from companies that bear the cost during workers have accidents in work.

\section{B. K3 training factors on the occurrence of work accident}

Based acyl h this study showed that of the 162 respondents mostly never follow the training $\mathrm{K} 3$ and never had an accident as much as 82 respondents (50.6\%), and logistic regression statistical test with the results of $p$-value $=0.039$, meaning $<0,05$, so $\mathrm{H} 1$ accepted and Ho rejected which means there is influence of K3 training on work accident in CV. Pacific Harvest Muncar Banyuwangi.

The results of this study are similar to the results of previous research conducted by Chess (2015) which examines the relationship of K3 training and occupational risk perception at altitude elevation in PT X Project Y Bekasi. Based on the results of the correlation test using Person Product Moment Sig value. (2-tailed) of 0.000 and Pearson correlation 0,541. The result shows that the value of Sig. (2-tailed) $<\alpha(0.000<0.05)$, it can be concluded that Ho is rejected and Ha accepted so that there is a significant relationship between giving $\mathrm{K} 3$ training and perception of risk of work accident at altitude at PT. X Project Y.

Training to safety and occupational health is one of the factors that become the control of unsafe acts committed by workers. However, the training aspect does not appear to play an important role in the implementation of occupational safety and health in the field (Murti, 2015).

Each new worker should receive sufficient training prior to carrying out the task according to the responsibilities given. The training provided should match the needs of the work area of each worker. To ensure that new workers have mastered the assigned tasks and responsibilities, it will require benchmarks as feedback from the training provided. Training is not only given to new workers, but other workers should be given refresher training. The management company should create an annual training program covering new topics as well as old topics as a re-fresh training. (Rendy, 2017).

The results show that there are still many employees CV. Pacific Harvest who has never attended K3 training. K3 training and training is one of the efforts that can be done by company management in suppressing the risk of work accident. The presence of training and training $\mathrm{K} 3$ can improve the skill or ability of employees in the work so that employees in work always pay attention to risk factors. While employees who have been trained $\mathrm{K} 3$ will certainly better know the procedures work more healthy and not dangerous. This situation is in line with the opinion of Hariandja (1993) which suggests that the need to improve work ability as a requirement in increasing productivity, the company continues to make efforts to improve the skills, knowledge and skills of employees through training or training so as to give great results on employee behavior in work. Companies can provide $\mathrm{OSH}$ education and training to employees during the training period or for newly admitted employees.

\section{Factors of use of PPE on the occurrence of accidents}

Based on the results of this study showed that of the 162 respondents almost entirely using appropriate PPE and never had an accident a total of 147 respondents (90.7\%), and logistic regression statistical test with the results of $p$-value $=0.023$, meaning $<0.05$, so $\mathrm{H} 1$ accepted and Ho rejected which means there is influence of the use of PPE to work accident in CV. Pacific Harvest Muncar Banyuwangi.

The results of this study are similar to the results of previous research conducted by Winasis (2016) who examines the analysis of the use of personal protective equipment (APD) to the level of accidents at PT. PAL Indonesia. Based on the level of work accident in the workshop of fabrication of stomach shows that from 44 respondents, who have experienced accidents as many as 11 people (25\%) and who never had work accident as many as 33 people $(75 \%)$. Based on the analysis of crosstabulation shows that there are 7 people (16\%) who use PPE have experienced accidents and workers who do not use APD as many as 4 people $(9 \%)$ who have experienced work accident. 
The practice of using personal protective equipment (PPE) is also very influential in worker safety. The physical environment and the management of companies that have not implemented the safety system are also the factors of occupational accidents. (Atmanto, 2011).

Tools that have the ability to protect a person in a job whose function is to isolate workers from hazards in the workplace (Permenakertrans No.08 / Men / VII / 2010), in other sense the similarity and effectiveness of the use of PPE for example, too large glasses will trouble the workers in the hairnet is too large to cause discomfort during use, shoes that are too large or materials that do not have good air circulation makes the workers uncomfortable or hot feet when used.

In order to minimize the occurrence of work accidents management company CV. Pacific Harvest prior to carrying out the work always provide counseling about the usefulness and function of personal protective equipment. Personal protective equipment, but the lack of awareness of employees makes the potential risk of accidents getting bigger. High potential and hazard factors will always accompany each job, then personal protective equipment (PPE) is indispensable as a form of protection against labor. Personal Protective Equipment is a set of safety equipment used by workers to protect all or part of its body from the possibility of exposure to potential workplace hazards to occupational accidents and diseases. Based on the results of the research note that the company has provided PPE with good quality standard but due to kealfaan or indiscipline some employees are often at risk of accidents such as when using headgear that is not in accordance with the reasons not free to move during the activity, so that the protective device itself as - did not help them in doing their job even impressed.

\section{Workload factor on the occurrence of work accident}

Based on the results of this study showed that from 162 respondents most of the light work load and never had an accident as much as 129 respondents $(79,6 \%)$, and statistical test of logistic regression with result of $p$-value $=0,938$, which means $>0,05$, so $\mathrm{H} 1$ rejected and Ho accepted which means there is no effect of workload on work accident in CV. Pacific Harvest Muncar Banyuwangi. The results of this study are similar to the results of previous research conducted by Nugraheni (2015) who examined the relationship between physical workload and work fatigue on the labor of concrete reinforcement in PT Wijaya Karya Beton Tbk. PPB Majalengka. Data analysis used Spearman-Rho correlation statistic test with significant level $(\alpha=0,05)$. The result of statistical test using SpearmanRho found a significant correlation between physical workload and work fatigue $(\mathrm{p}=0,000)(\mathrm{r}=$ 0,714 ) with strong relationship level and indicated positive kore lasi direction. From the research results can be concluded there is a relationship between physical workload with fatigue.

Workload (workload) is a role relationship stressors or other tasks that occur because employees feel the strain was too much. This can be due to the company reducing its workforce and restructuring the work, leaving the rest of the employees with more tasks and less time and resources to complete (Sophia, 2008).

The main factors that determine the workload are the demands of task, effort, and performance (Tarwaka 2010): 1) the factor of task demand. The argument relating to this factor is that the workload can be determined from the analysis of tasks performed by the worker; 2) Business or energy. The amount of energy spent in a job may be an intuitive form naturally to the workload; 3 ) Performation. Most studies on workloads are concerned with the level of performance to be achieved. Workload is something that arises from the interaction between task demands, work environment where it is used as a workplace, skills, behavior and perceptions of workers. Workloads can sometimes be defined operationally on various factors such as task demands or attempts to do the work.

The results showed that there was no influence between workload and work accident. For employees of CV. Pacific Harvest Muncar, especially in the production section of work that is now done is not hard work, so this has no effect on their physical condition. Work done on a regular and continuous basis will make a light of a job. Besides, in their processing the processed products do not require skill or special ability. Therefore for them the work done today is a routine work that is commonly done so that for them this work is not burdensome. 


\section{E. Factor working hours against the occurrence of work accidents}

Based on the results of this study showed that of the 162 respondents mostly have appropriate working hours and never had an accident as much as 137 respondents (84.6\%), and logistic regression statistical test with the results of $p$-value $=0.699$, which means $>0.05$, so $\mathrm{H} 1$ rejected and Ho accepted which means no effect of working hours against work accident in CV. Pacific Harvest Muncar Banyuwangi.

The results of this study are similar to the results of previous research conducted by Aswar (2016) who examines the factors associated with workplace accidents in car workshop workers Kendari City. The result of this research shows that there is no correlation between work duration and work accident where $\mathrm{P}$ Value $>\alpha$, there is correlation between work fatigue with work accident where $\mathrm{P}$ Value $<\alpha$ with relationship value of two medium value variables $(\mathrm{phi}=0,471$ ) work with work accidents where the value of Pvalue $<\alpha$ with the value of the relationship of two strongly valuable variables (phi $=0.582$ ), there is a relationship between knowledge $\mathrm{K} 3$ with work accidents where the value of Pvalue $<\alpha$ with the value of the two strong value variables ( $\mathrm{phi}=0.655$ ) between the use of PPE with the work accident where the value of Pvalue $<\alpha$ with the value of the relationship between the two variables are medium value $(\mathrm{phi}=0.418)$.

Working hours are working time including rest time. The working time of a person determines its efficiency and productivity. A person can work well in a day for 8 hours or 40 hours a week. Leftover time in a day (16 hours) is used for life in family and society, rest and others (Suma'mur, 2011).

The length of working time is related to the physical condition of the worker's body. The length of work for a person determines its efficiency and productivity. Severe physical work will affect muscle work, cardiovascular, respiratory and other systems. If the work lasts for a long time without rest, the body's ability will decrease and can menbabkan pain in the limbs, will experience fatigue work resulting in work accidents. With extended working hours can cause fatigue and increase the risk of accidents while working. Working time is just one factor that may affect the occurrence of an accident.

\section{CONCLUSION}

In this research can be concluded as follows:

1. There is an effect of $\mathrm{K} 3$ assurance against work accident in CV. Pacific Harvest Muncar Banyuwangi ( $p$-value $=0.022<0.05)$.

2. There is an effect of K3 training on work accident in CV. Pacific Harvest Muncar Banyuwangi $(p$-value $=0.039<0.05)$.

3. There is influence of usage of APD to accident at CV. Pacific Harvest Muncar Banyuwangi ( $p$-value $=0.023<0.05)$.

4. There is no effect of work load on work accident in CV. Pacific Harvest Muncar Banyuwangi $(p$-value $=0.938>0.05)$.

5. There is no effect of working hours on work accident in CV. Arvest Pacific Muncar Banyuwangi $(p$-value $=0.699>0.05)$.

\section{SUGGESTION}

1. For respondents

Employees should pay more attention to occupational health and safety while doing their jobs, because of the many factors that can lead to work accidents, the use of personal protective equipment that is in accordance with the rules and always pay attention to the condition of the field as well as safe action in work will reduce the risk of work accident 


\section{2. $\quad$ For research sites}

The company's management is expected to pay more attention to the work environment by providing signs / signs on risky places as well as work equipment such as the completeness of Personal Protective Equipment provided for workers. In addition it is expected to increase supervision on the unsafe behavior of workers in doing the job.

3. For Further Researchers

For researchers who will carry out further research in order to add some other variables that also have a close link to accidents.

\section{REFERENCES}

Aswar, E. (2016). Faktor-Faktor Yang Berhubungan Dengan Kecelakaan Kerja Pada Pekerja Bengkel Mobil Kota Kendari Tahun 2016. http://ojs.uho.ac.id/index.php/JIMKESMAS/article/viewFile/1215/862.

Atmanto, I. (2011). "Behavioral Determinants Workers In The Use Of PPE Based on Hazard Assessment in Foundry Company Ceper Klaten”. Jurnal Publikasi, ISBN. 978-602-99334-0-6. Semarang: UNDIP.

Detiknews. (2017). 14.552 Kasus Kecelakaan Kerja Terjadi di Jatim Sepanjang 2017. https://news.detik.com/berita-jawa-timur/d-3810738/14552.

Djumena, (2011). Kecelakaan Kerja di Indonesia Tergolong Tinggi. http://bisnis keuangan. kompas.com/.

Efendy, \& Makhfudli. (2010). Keperawatan Kesehatan Komunitas: Teori dan Praktik dalam Keperawatan. Jakarta: Medika Salemba.

Kusuma, I., J. (2010). Pelaksanaan Program Keselamatan Dan Kesehatan Kerja Karyawan PT. Bitratex Industries Semarang. Jurnal Studi Manajemen \& Organisasi Vol. 7 No. 1 2010. http://eprints.undip.ac.id/ $35594 / 1 /$.

Nugraheni. (2015). Hubungan antara beban kerja fisik dengan kelelahan kerja pada tenaga kerja bagian produksi tulangan beton di PT Wijaya Karya Beton Tbk. PPB Majalengka. ttp://eprints.ums.ac.id/37600/.

Peraturan Pemerintah No. 50 Tahun 2012 tentang Penerapan Sistem Manajemen. K3.

Rendi, A., S. (2017). Pentingnya Training K3 Untuk Mengurangi Dampak Kerugian. http://jurnalk3lh.web.id/2017/02/25/.

Safrianto. (2017). Pengaruh pemberian jaminan kecelakaan kerja dan jaminan kematian bpjs ketenagakerjaan terhadap produktivitas kerja karyawan PT. Mitsubishi Krama Yudha Motors \& Manufacturing. http://ojs.ekonomi-unkris.ac.id/index.php/JMBK/article/download/108/pdf.

Sophia. (2008). Perilaku Organisasi. Edisi I. Yogyakarta: C.V Andi Offset.

Suma’mur. (2011). Keselamatan Kerja Dan Pencegahan Kecelakaan. Jakarta: CV Haji Masagung.

Taufik, H. (2015). Tinjauan Penerapan Sistem Manajemen Keselamatan Dan Kesehatan Kerja (SMK3) (Studi Kasus: Pembangunan Gedung Telkomsel Pekanbaru). Annual Civil Engineering Seminar 2015, Pekanbaru ISBN: 978-979-792-636-6. http://download.portalgaruda.org/article.php?article= 386165 .

Tarwaka. (2015). Ergonomi Industri Dasar-Dasar Pengetahuan Ergonomi Dan. Aplikasi di Tempat Kerja. Surakarta: Harapan Press.

Trijono, \& Rachmat. (2014). Pengantar Hukum Ketenagakerjaan, Depok: Papas Sinar Sinanti.

Winasis, S. (2016). Analisis penggunaan alat pelindung diri (APD) terhadap tingkat kecelakaan kerja di PT. PAL Indonesia. http://jurnal.unipasby.ac.id/index.php/waktu/article/download/05/33/. 